\title{
O NÃO SABER SOCRÁTICO E A EDUCAÇÃO: O DESAFIO DE APRENDER A PENSAR
}

Giorgio Borghi*

\begin{abstract}
RESUMO
Este artigo analisa o problema do tipo de saber que está em jogo na educação, refletindo sobre o sentido do não saber socrático que se contrapõe ao saber tradicional da pólis e ao novo saber dos sofistas. Considerando a relação entre saber e pensar, a nossa atenção se concentra sobre o diálogo platônico Apologia de Sócrates, onde encontramos a primeira tematização do conflito entre a visão tradicional e a visão filosófica da educação. Para uma correta compreensão desse conflito é necessário entender a nova relação que a filosofia inaugura com a dimensão transcendente da verdade, que se torna decisiva para uma paideia de tipo socrático, a ponto de ser considerada motivo suficiente para a condenação à morte do filósofo. O que torna ameaçadora a atitude de Sócrates em relação à educação é o seu misticismo filosófico monoteísta, que relativiza tanto o antropomorfismo das verdades consideradas intocáveis pelos religiosos, como o antropocentrismo absoluto da visão dos sofistas.
\end{abstract}

Palavras-chave: Saber. Pensar. Educação. Filosofia.

\section{ABSTRACT \\ THE NOT-KNOWING SOCRATIC AND EDUCATION: THE CHALLENGE OF LEARNING HOW TO THINK}

This article analyzes the problem of the kind of knowledge that is at stake in education. We reflect on the Socratic meaning of not-knowing opposed to the traditional knowledge of the polis and to the new knowledge of the Sophists. Considering the relation between knowing and thinking, our attention focuses on the Platonic dialogue Apology, in which we find the first thematization of the conflict between the traditional view and the philosophical view of education. For a correct understanding of this conflict it is necessary to understand the new relation that philosophy inaugurates through the transcendent dimension of truth, which becomes decisive for a Socratic kind of Paideia, that was considered enough to condemn the philosopher to death. What makes the Socratic attitude threatening in relation to education is his monotheistic philosophical mysticism, which shows the relativity of both anthropomorphism of the truths that are considered untouchable by religious men and the absolute anthropomorphism vision of the Sophists.

Keywords: Knowing. Thinking. Education. Philosophy.

\footnotetext{
* Doutor em Filosofia pela Universidade de Bologna. Professor Emérito da Faculdade São Bento da Bahia. Endereço para correspondência: Avenida Oceânica, 2353, Ap. 804, Ondina, Salvador-BA. CEP: 40170-010. giorgioborghi@hotmail.com
} 
A questão do saber e do não saber é considerada central quando se fala em educação, mas, afinal, o que significa 'saber'? A filosofia e a prática educativa socrática colocam radicalmente o problema do tipo de saber que está em jogo na educação e é justamente este problema que o presente artigo se propõe analisar. Somos desafiados a repensar as dimensões do nosso conhecimento e os nossos paradigmas pedagógicos, recuperando a doutrina socrática do "conhece-te a ti mesmo e reconhece quão pouco sabes"; uma doutrina que, conforme observa Popper (2006, p. 34), "foi banida pela crença de que a verdade é manifesta e pela nova confiança do homem em si próprio, exemplificada e ensinada de diferentes modos por Lutero e Calvino, Bacon e Descartes".

A visão moderna de conhecimento nos acostumou a identificar o saber com a certeza. Descartes teoriza que os estudos devem ter por objeto somente aquilo que estiver acima de qualquer dúvida e, na terceira das Regras para a direção do espírito, assim declara:

Sobre os objetos propostos ao nosso estudo, é necessário procurar não o que os outros pensaram ou o que nós mesmos conjecturamos, mas aquilo de que podemos ter uma intuição clara e evidente, ou o que podemos deduzir com certeza. Pois não é de outro modo que a ciência se adquire. (DESCARTES, 2010, p. 410).

Hoje sabemos que também o conhecimento científico é sempre e somente conhecimento humano e, portanto, "está misturado com os nossos erros, os nossos preconceitos, os nossos sonhos e as nossas esperanças" (POPPER, 2006, p. 52). Além disso, acreditamos que a dimensão de mistério é constitutiva da nossa existência humana no mundo e que o nosso conhecimento, enquanto conhecimento humano, jamais poderá prescindir desta dimensão do nosso ser. Isso significa abrir-se a uma dimensão transcendente do processo educativo, que valoriza mais o pensar do que o saber. Existe uma diferença entre pensar e saber.

Pois pensar não é saber. É não saber. Quando se pensa não se pretende saber; e quando se pretende já saber, não se pensa. [...] Por isso só aprende quem pensa. Pois pensar significa acolher o mistério da realidade irrompendo nas realizações do real. (LEÃO, 2003, p. 27).
Somente quem reconhece o seu não saber frente ao "mistério da realidade" encontra-se na condição de aprender a pensar e de aprender pensando. Mais que simplesmente acumular conhecimento, o importante é aprender a pensar. Já no século XVI, Montaigne (1996, p. 140) escrevia que precisava "indagar quem sabe melhor e não quem sabe mais", e não se preocupar "por guarnecer a memória, deixando de lado, e vazios, juízo e consciência".

Trata-se de integrar a "sociedade do conhecimento" com a "sociedade do pensamento", para que as pessoas, que hoje têm acesso a uma infinidade de informações, possam desenvolver também a capacidade de pensar. $\mathrm{O}$ conhecimento é matéria-prima do pensamento: mas o conhecimento adquire todo o seu valor quando é administrado pela capacidade de pensar. Por isso, é fundamental que a educação ajude as pessoas a aprender a pensar, para poder valorizar o conhecimento, porque o pensar humano educado não leva à certeza, como queria Descartes, mas à capacidade de lidar com as incertezas e a uma atitude de diálogo e tolerância, que é decisiva para a qualidade ética da convivência humana.

Tudo se submeterá ao exame da criança e nada se lhe enfiará na cabeça por simples autoridade e crédito. Que nenhum princípio, de Aristóteles, dos estoicos ou dos epicuristas, seja seu princípio. Apresentem-se-lhe todos em sua diversidade e que ela escolha se puder. E se não puder fique na dúvida, pois só os loucos têm certeza absoluta em sua opinião. (MONTAIGNE, 1996, p. 152).

E continua com uma citação de Dante Alighieri: "Não menos que saber, duvidar me apraz"1 (MONTAIGNE, 1996, p. 152). Esse duvidar não corresponde à dúvida metódica de Descartes, que é finalizada ao adquirir a certeza do conhecimento, mas coloca-se como alternativa a um tipo de saber que exclui a dimensão transcendente da verdade. Trata-se, portanto, de uma dimensão de espírito que podemos chamar de espiritualidade do conhecimento e que entra constitutivamente numa nova visão de educação; não é por acaso que Sócrates é condenado como corruptor da juventude e corruptor porque ímpio.

A figura de Sócrates encarna a nova visão de educação que vem se definindo com o apareci-

1 "Che non men che saber, dubbiar m' agrada". 
mento do pensar filosófico e é no diálogo platônico Apologia de Sócrates que encontramos a primeira tematização do conflito entre a visão tradicional e a visão filosófica da educação. Conflito que articula estritamente a questão da educação com a questão da "piedade" e que tem um desfecho dramático com a condenação à morte do filósofo, mostrando a grande relevância que as questões da educação e da religiosidade tinham para as pessoas envolvidas nesse conflito.

Sócrates, que Jaeger (1979, p. 475) considera como "o mais espantoso fenômeno pedagógico da história do Ocidente", é condenado como um sujeito perigoso para a educação e é a falta de "piedade" que se torna prejudicial para a educação da juventude, segundo a acusação de Meleto. Ora, o nosso intento é mostrar que essa tese da acusação contra Sócrates é correta, mas em sentido totalmente diferente daquilo que entendia Meleto, porque o que entra em choque no processo de condenação de Sócrates são visões profundamente diversas de educação e do tipo de "espiritualidade" que orienta o processo educativo e que é definido pela relação que o educador tem com a verdade.

No diálogo platônico, a acusação formal do processo é resumida pelo próprio Sócrates da seguinte maneira: Sócrates "é culpado de corromper os moços e não acreditar nos deuses que a cidade admite, além de aceitar divindades novas" (PLATÃO, 2001, p. 122-123). A ligação entre as duas acusações aparece claramente pouco depois:

Não obstante, declara-nos, Méleto, porque motivo andas a espalhar que eu corrompo os jovens? Segundo a queixa que apresentaste, deve ser por ensiná-los a não acreditar nos deuses em que a cidade acredita, porém em demônios de nova modalidade. Não é isso o que afirmas: que com essa doutrina eu os corrompo? (PLATÃO, 2001, p. 125).

Meleto confirma que é precisamente isso que ele está dizendo. Solicitado a esclarecer melhor se a acusação refere-se simplesmente ao fato de introduzir novos cultos ou à recusa de venerar aos deuses, Meleto responde significativamente, embora de forma não muito coerente: "O que afirmo é que não acreditas absolutamente na existência dos deuses" (PLATÃO, 2001, p. 126). Com isso estão colocados os elementos decisivos de um confronto que, para além da aparente leviandade e inconsistência da acusação, assume uma relevância que atravessa os séculos, chegando até nós.

O que está em jogo no processo a Sócrates é muito mais sério e profundo do que a formulação verbal das acusações deixaria acreditar, adquirindo a característica de um processo formal à filosofia nascente. Não é por acaso que Sócrates precisa esclarecer, mais de uma vez, que ele está sendo acusado incorretamente de coisas que pertenciam ao pensamento de filósofos naturalistas ou sofistas, como já tinha acontecido na comédia As nuvens, de Aristófanes. "Sócrates erra por investigar indevidamente o que se passa embaixo da terra e no céu, por deixar bons os argumentos ruins e também por induzir outros a fazerem a mesma coisa" (PLATÃO, 2001, p. 115).

Quando um povo precisa de um bode expiatório contra uma suposta perigosa ameaça, não importa a consistência ou a coerência do procedimento inquisitório. Que Sócrates de fato compartilhasse do pensamento dos naturalistas ou dos sofistas é um detalhe insignificante tanto para Meleto quanto para a maioria que o condenou. No tribunal, Sócrates estava representando a ameaça que provinha do novo pensar filosófico e por isso estava sendo julgado. A única saída possível, para ele, seria desistir de filosofar, não tanto tentar justificar a sua filosofia ou tentar esclarecer que não é a mesma de outros pensadores. Sócrates percebe claramente isso, quando imagina o que poderiam propor-lhe os juízes:

Sócrates, não daremos atenção a Ânito; vamos absolver-te, com a condição de parares com essa investigação e não te dedicares de hoje em diante à filosofia; porém, se fores mais uma vez apanhado nessas práticas, morrerás por isso. (PLATÃO, 2001, p. 130).

A condenação de Sócrates fica praticamente decretada pela resposta que ele dá a essa proposta que seria a única condição de absolvição: "Estimo-vos, atenienses, e a todos prezo, porém sou mais obediente aos deuses do que a vós, e enquanto tiver alento e capacidade, não deixarei de filosofar" (PLATÃO, 2001, p. 130).

\section{O perigo do não saber socrático}

Nessa altura da nossa reflexão, torna-se necessário entender porque o tribunal ateniense consi- 
derava tão perigosa a prática filosófica, a ponto de justificar a condenação à morte daquele que, no momento, era o seu mais significativo representante.

As acusações formuladas no processo indicam claramente que o que mais preocupa os acusadores, em relação à filosofia, é justamente a questão da educação, estritamente atrelada ao modo de considerar a relação com o "divino". Não é possível desvincular a questão do conhecimento da questão da educação; e a filosofia se ocupa, desde o seu nascimento, com uma nova concepção de conhecimento, que encontra na atitude socrática o seu desenvolvimento ético e que, por conta disso, acaba envolvendo mais diretamente o problema educacional. Sócrates não se refere à sua atividade com a palavra educação (paideia), porque considera representantes oficiais da paideia do seu tempo Górgias de Leontini, Pródico de Ceos e Hípias de Élis (PLATÃO, 2001, p. 116), dos quais quer claramente se diferenciar. Neste sentido, "nunca ensinei pessoa alguma” (PLATÃO, 2001, p. 135), declara Sócrates. Mas,

Através dele, a missão de toda a educação é banhada por uma luz nova: já não consiste no desenvolvimento de certas capacidades nem na transmissão de novos conhecimentos; [...]. Identifica-se com a aspiração socrática ao conhecimento do bem, com a phronesis. E esta aspiração não se pode restringir aos poucos anos duma chamada cultura superior. Só pode alcançar o seu objetivo ao longo de toda a vida do Homem; de outro modo não o alcança. Isto faz mudar o conceito de essência da paideia. A cultura em sentido socrático converte-se na aspiração a uma ordenação filosófica consciente da vida, que se propõe cumprir o destino espiritual e moral do Homem. (JAEGER, 1979, p. 532).

A questão do conhecimento como sabedoria é tema central da Apologia de Sócrates, porque é justamente o questionamento em relação à efetiva sabedoria da cultura tradicional que mais incomoda aqueles que se consideram os responsáveis pela tradição e pelos bons costumes. "Semelhante fama, atenienses, não me veio senão de certa sabedoria que me é própria. Que espécie de sabedoria?" (PLATÃO, 2001, p. 117). O oráculo que declara Sócrates como o mais sábio provoca o filósofo a empreender uma pesquisa sobre o sentido desta afirmação que leva a uma nova definição de saber e de sabedoria. Depois de sondar políticos, poetas e artesãos, Sócrates sinaliza a lacuna comum do tipo de conhecimento deles: "pelo fato de cada um deles conhecer a fundo determinada profissão, julgavam-se também proficientes nas questões mais abstrusas, donde estragar esse defeito fundamental de todos a sabedoria de cada um" (PLATÃO, 2001, p. 120). Portanto, a superioridade da sabedoria socrática define uma nova atitude de conhecimento, de relacionamento com a verdade, que desafia toda a cultura vigente. Finalizando a sua entrevista com um político, Sócrates declara:

Depois, ao retirar-me, falava a sós comigo: mais sábio do que este homem terei de ser, realmente. Pode bem dar-se que, em verdade, nenhum de nós conheça nada belo e bom; mas este indivíduo, sem saber nada, imagina que sabe, ao passo que eu, sem saber, de fato, coisa alguma, não presumo saber algo. (PLATÃO, 2001, p. 119).

Questionando o saber da pólis, representado pelos seus mais cultos expoentes, o filósofo questiona também o sistema educacional e denuncia que, na realidade, os dirigentes da cidade brincam com coisas sérias, como Meleto, "com fingido zelo, a respeito de assunto a que nunca atribuiu a mínima importância" (PLATÃO, 2001, p. 123). E essa leviandade em relação à educação aparece claramente no único momento realmente dialógico da Apologia, quando Sócrates interroga Meleto sobre quem corrompe e quem torna melhores os jovens. Se ele está acusando Sócrates de corromper a juventude, deve ter claro o que significa educar os jovens e quem os pode tornar melhores. A reticência de Meleto em responder mostra a dificuldade dele em acompanhar um diálogo reflexivo, por não estar acostumado a "pensar", mas estar simplesmente expressando o senso comum daqueles que estão convencidos de que "um celerado de nome Sócrates anda a corromper os moços. Mas, se alguém lhes pergunta de que se ocupa e o que ensina, não têm o que dizer, porque de todo o ignoram. E, para encobrirem sua perplexidade, recorrem a essas imputações vulgares comumente assacadas contra os amantes da Sabedoria" (PLATÃO, 2001, p. 121-122).

A dificuldade de Meleto em pensar a educação se mostra logo na sua resposta à insistência 
de Sócrates, que o obriga a dizer alguma coisa. Sócrates está perguntando "quem" torna melhores os jovens, e Meleto responde: "As leis". Trata-se de uma resposta particularmente significativa, que revela muito da visão de educação tradicional que se incomoda com a filosofia. Por que se preocupar com "quem" deveria educar os jovens? As próprias leis e instituições da cidade, por si mesmas, os tornam virtuosos, levando-os a prestigiar o que a cidade prestigia e a desprezar o que a cidade despreza. Nenhuma educação seria mais certa e eficaz, se entre as instituições da pólis e os jovens não se intrometessem os filósofos, contaminando-os com a praga do pensamento reflexivo, que os afasta da adesão espontânea e natural ao que todo mundo sente e pensa.

Sócrates não desprezava as instituições da pólis; muito pelo contrário, ele estava pronto a testemunhar com a morte o seu respeito para as leis da cidade. Contudo, para ele, quando se trata de educação, não basta o contato direto com as instituições da cidade sem a mediação de alguém que pensa e que sabe ajudar os jovens a aprender a pensar com a própria cabeça. Sócrates, portanto, não pode aceitar a resposta de Meleto, que indica as leis como responsáveis diretas pela educação da juventude, e reformula de forma mais explícita a sua pergunta. "Não foi isso que te perguntei, meu caro, porém o homem, que terá, naturalmente, para começar, de conhecer as leis" (PLATÃO, 2001, p. 123).

Novamente a resposta de Meleto decepciona, mostrando que sua aversão a Sócrates prejudicou realmente a sua capacidade de pensar. A pergunta de Sócrates tentava conduzir Meleto a se concentrar sobre a figura humana do educador (não "o que", mas "quem", qual pessoa), que naturalmente deverá também conhecer as leis; Meleto considera somente o final da pergunta e responde que quem conhece as leis são os juízes. Trata-se de uma resposta estrategicamente correta, na perspectiva do acusador, mas que mostra, mais uma vez, a incapacidade de pensar a educação. Será que os juízes deviam ser considerados todos bons educadores, pelo simples fato de serem bons conhecedores das leis?

E mais: além dos quinhentos juízes, havia muitas pessoas assistindo como ouvintes e um correto senso democrático comportava reconhecer que elas também tinham conhecimento das leis e, só por isso, conforme a opinião de Meleto, elas também seriam idôneas para educar. O mesmo senso democrático não podia deixar de fora os membros do Senado (outra instituição de quinhentas pessoas) e a Assembleia popular de todos os cidadãos com direito de voto, que, naturalmente, conhecendo as leis, se encontravam todos em condição de serem bons educadores dos jovens. Então, conclui Sócrates, "Ao que parece, todos os atenienses os deixam bons e nobres, menos eu. Sou o único a corrompê-los". E Meleto confirma: "Exatamente" (PLATÃO, 2001, p. 124).

Sócrates não quer contestar, diretamente, essa extrapolação democrática que reconhece competência educativa a todos os cidadãos; por isso, prefere continuar o diálogo dando uma volta estratégica no mundo dos cavalos e dos outros animais, onde é incontestável que somente bem poucos sabem como lidar com estes seres viventes para torná-los melhores. Meleto acredita no automatismo educativo das instituições políticas e vê na majestade das leis a eficácia formativa dos jovens; Sócrates está constantemente interessado no valor da pessoa singular e procura homens que saibam educar individualmente.

A continuação do diálogo de Sócrates com Meleto, vertendo sobre a acusação de impiedade e de ateísmo, evidencia o ponto crucial da divergência das visões educacionais que aqui se confrontam. Parece que a acusação de Meleto é uma brincadeira. "Pois quer parecer-me que ele se contradiz na sua acusação. É como se dissesse: Sócrates é culpado por não acreditar nos deuses, mas acredita que existem deuses. Positivamente, tudo isso não passa de pilhéria" (PLATÃO, 2001, p. 126). Entretanto, de novo, Meleto e os outros acusadores de Sócrates consideram como detalhe que ele ensine a venerar outros deuses ou a não venerar de modo algum aos deuses. O que interessa e incomoda profundamente é que a filosofia e a educação de Sócrates nascem e se alimentam de uma atitude de espírito, uma "espiritualidade" outra, uma espiritualidade que pode até ser considerada ateia pela religiosidade tradicional. A acusação é apresentada de forma ingênua e incoerente, mas capta o que realmente é muito perigoso e ameaçador no pensamento e na paideia filosófica socrática. Como observa Jaeger (1979, p. 
539-540), falando de Sócrates, "o conhecimento da essência e da força do bem, que se apodera do seu interior como força arrebatadora, converte-se para ele num novo caminho para encontrar o Divino".

\section{A espiritualidade filosófica monoteísta}

A questão da religiosidade na Apologia de Sócrates coloca-se em estreita relação ao tema do conhecimento e da sabedoria. A superior sabedoria socrática, que se funda sobre a consciência de não saber, comporta a seguinte convicção:

Mas o que eu penso, senhores, é que em verdade só o deus é sábio, e que com esse oráculo queria ele significar que a sabedoria humana vale muito pouco e nada, parecendo que não se referia particularmente a Sócrates e que se serviu do meu nome apenas como exemplo, como se dissesse: Homens, o mais sábio dentre vós é como Sócrates, que reconhece não valer, realmente, nada no terreno da sabedoria. (PLATÃO, 2001, p. 121).

A verdadeira sabedoria implica o reconhecimento da dimensão transcendente da verdade, um reconhecimento que modifica radicalmente também a atitude e a modalidade educacional.

Para Sócrates, viver filosofando significa dedicar-se ao conhecimento de si e dos outros e configura-se como obediência a uma ordem divina, para o bem individual e coletivo. "É o que me ordena fazer a divindade, bem o sabeis, estando eu convencido de que nunca nesta cidade vos tocou por sorte maior bem do que o serviço por mim a ela prestado" (PLATÃO, 2001, p.131). A Apologia de Sócrates é talvez o escrito platônico em que aparece com mais frequência a palavra deus, no singular. Esse monoteísmo filosófico, no contexto de uma cultura religiosamente politeísta, nos convida a um exame cuidadoso e aprofundado desta nova atitude espiritual, que aparece desde o próprio nascimento da filosofia.

Maria Zambrano abre o primeiro capítulo do seu livro $O$ Homem e o Divino com a seguinte afirmação: "Uma cultura depende da qualidade dos seus deuses" (ZAMBRANO, 1995, p. 25). Assim, podemos dizer que a passagem da mitologia à filosofia se apresenta como uma mudança cultural determinada pela diferença qualitativa da percepção do divino. "Pois a acção por excelência da filosofia foi a transformação do sagrado no divino, na pura unidade do divino. E para realizar esta acção impremeditada de transformar o sagrado no divino, o pensamento filosófico teve de ignorar os deuses, imagens" (ZAMBRANO, 1995, p. 67-68).

O sagrado nasce da pretensão do conhecimento humano de conhecer e controlar o mistério. Transformar o sagrado no divino significa aceitar não poder abarcar totalmente a riqueza inesgotável do mistério da vida e do mundo e ter a coragem de mergulhar na escuridão de um não saber, onde formular novamente a pergunta mais simples e mais radical: “o que é isso?”. É justamente essa pergunta que caracteriza a pedagogia irônica e maiêutica de Sócrates e que revela uma nova percepção da transcendência da verdade.

É esse retorno ao divino que dá início ao pensamento filosófico. Um retorno que, descendo as camadas cada vez mais profundas da ignorância, nos leva no âmago das trevas originárias da realidade e do ser, onde as imagens sagradas da mitologia não satisfazem mais. Sim, porque os antigos mitos gregos não podem ser considerados, simplesmente, curiosas histórias de seres fabulosos chamados deuses, mas como a tentativa de sondar e "compreender" a profundidade oculta da realidade. Quando Tales elabora a sua hipótese da água como princípio ontológico e gnosiológico de todas as coisas, está procurando uma nova forma de resposta à mesma questão da qual tinha se originado o pensamento mitológico. Por isso, mais que uma hipótese científica, no sentido atual da palavra, está propondo uma nova atitude de conhecimento da realidade, que se fundamenta numa nova concepção do divino.

O próprio Aristóteles lembra que Tales teria apresentado uma segunda tese, aparentemente contraditória com aquela, mais conhecida, da água: "Tudo está cheio de deuses". Será que essas duas teses, a da água e a dos deuses, são afirmações conflitantes, ou será que elas indicam o caminho para a verdadeira compreensão do sentido que a teoria de Tales tinha, na época em que foi formulada? Quando Aristóteles fala de Tales, na Metafísica, inicia apresentando aquela que poderíamos considerar a primeira definição do método científico como aquilo que nos permite deduzir hipóteses e leis gerais a partir de observações e experimentos: "Tales, iniciador desse tipo de filosofia, diz que o princípio 
é a água [...], certamente tirando esta convicção da constatação de que [...]”' (ARISTÓTELES, 2001, p. 17); mas depois continua, dizendo:

Há também quem acredite que os mais antigos, que por primeiro discorreram sobre os deuses, muito antes da presente geração, também tiveram essa mesma concepção da realidade natural. De fato, afirmaram Oceano e Tétis como autores da geração das coisas, e disseram que aquilo sobre o quê juram os deuses é a água, chamada por eles Estige. (ARISTÓTELES, 2001, p. 17).

Essa evocação, feita por Aristóteles, do antiquíssimo saber mítico sobre o Oceano, Tétis e Estige, o lendário rio original, e a surpreendente menção aos "que por primeiro discorreram sobre os deuses", que coloca também Tales entre aqueles que especularam a respeito dos deuses, nos oferece uma preciosa sugestão interpretativa do pensamento dele, que supera o aparente conflito entre suas teses. Quando fala de água, Tales está tentando dizer algo sobre o mistério da origem, sem recorrer às imagens sagradas da mitologia.

Do mesmo modo que a água dá vida às coisas, assim também se passa com o fundamento divino originário: vivifica tudo o que penetra. Desse modo, a frase de Tales sobre a originariedade da água pretende afirmar o seguinte: em todo o real atua uma força divina, de poder criador, assim como o rio originário do mito, que tudo penetra como a mantenedora da vida, a água (WEISCHEDEL, 2000, p. 22-23).

Segundo a interpretação de Nietzsche, no seu escrito A Filosofia na Época Trágica dos Gregos, a hipótese da água, que precisamos levar a sério porque enuncia algo sobre a origem das coisas "sem imagem e fabulação", é algo que Tales não poderia ter deduzido das "parcas e desordenadas observações da natureza empírica". O que levou Tales àquela que Nietzsche chama de "monstruosa generalização" foi um postulado metafísico, uma crença que tem sua origem em uma intuição mística e que encontramos em todos os filósofos, ao lado dos esforços sempre renovados para exprimi-la melhor - a proposição: "Tudo é um". (NIETZSCHE apud PRÉ-SOCRÁTICOS, 1996, p. 44).

Nietzsche destaca, assim, a intuição mística como algo que pertence ao código genético da filosofia enquanto tal.
O discípulo de Tales, Anaximandro, continua e aprofunda esse novo caminho, com a ideia genial do apeiron, que, pela própria formulação privativa, indica, ainda mais claramente, aquele retrocesso à ignorância de onde nasce a atitude filosófica, na busca de um divino originário sem imagens, sem definição (indefinido), sem limite (ilimitado). Todavia, quem primeiro tematizou a transformação do sagrado no divino, operada pela filosofia, foi Xenófanes de Cólofon, com sua crítica ao antropomorfismo da mitologia.

Tivessem os bois, os cavalos e os leões mãos, e pudessem, com elas, pintar e produzir obras como os homens, os cavalos pintariam figuras de deuses semelhantes a cavalos, e os bois semelhantes a bois, cada (espécie animal) reproduzindo a sua própria forma. (BORNHEIM, 2011, p. 32).

A vontade de verdade, como diria Nietzsche, leva o ser humano a querer, de qualquer jeito, dispor dela, pintando-a a sua imagem e semelhança, criando simulacros que possam dar a ilusão de dispor dela quando e como deseja. Mas o filósofo descobre que a verdade, na sua profundidade originária, é divina e, como tal, é sempre mais: “Um único deus, o maior entre deuses e homens, nem na figura, nem no pensamento semelhante aos mortais" (BORNHEIM, 2011, p. 33). Esta 'profissão de razão' monoteísta abre o caminho para a elaboração ontológica de Parmênides e para a ideia do Ser, como tradução da dimensão profunda e misteriosa da realidade. Como observa Heidegger,

De há muito, o mistério nos foi proposto na palavra 'ser'. É por isso que o 'ser' é apenas uma palavra provisória, no sentido de palavra precursora. Cuidemos que nosso pensamento não lhe corra apenas atrás, de olhos fechados. Pensemos que 'ser' significa originariamente 'vigência' e 'vigência' significa adiantar-se e perdurar no des-encobrimento da verdade. (HEIDEGGER, 2002, p. 203, grifo do autor).

\section{Misticismo filosófico e educação}

Esta volta às origens era necessária para entender melhor o deus de que tanto fala Sócrates, fonte de sua piedade e motivo do conflito dramático que o leva à morte. A acusação dele não acreditar nos deuses que os atenienses acreditavam tinha algo de 
verdadeiro, embora ele não desprezasse a religião popular. Mas a sua adesão incondicionada ao filosofar tinha operado nele a transformação do sagrado no divino, uma transformação que se manifestava na sua vida e na sua prática de educador. Uma primeira consequência disso era sua concepção de verdade.

Sócrates sempre desconfiou do óbvio e quase sempre consegue mostrar que o óbvio é irreal e que a verdade é muito raramente óbvia. $\mathrm{O}$ modo como mostra isso é a substância da discussão e dá a ela empolgação e dinamismo. Chegar a uma conclusão não é o objetivo. O objetivo é ensinar às pessoas com quem ele está conversando como pensar e, principalmente, como pensar por si mesmas. (JOHNSON, 2012, p. 72).

Considerar a verdade como não óbvia é a atitude básica da espiritualidade filosófica monoteísta, que já Xenófanes tinha delineado:

Pois homem algum viu e não haverá quem possa ver a verdade acerca dos deuses e de todas as coisas das quais eu falo; pois mesmo se alguém conseguisse expressar-se com toda exatidão possível, ele próprio não se aperceberia disso. A opinião reina em tudo. (BORNHEIM, 2011, p. 33).

Ora, precisamos relembrar que é justamente a falta dessa atitude de espírito, dessa "espiritualidade", que prejudica a efetiva sabedoria dos sabidos de Atenas que, pelo fato de conhecer bem alguma coisa, consideram-se sapientíssimos mesmo "nas questões mais abstrusas” (PLATÃO, 2001, p. 120).

Para saber quais são, para Sócrates, estas “outras matérias de grande importância" podemos recorrer a um resumo das recomendações dele ao cidadão de Atenas:

Como se dá, caro amigo, que, na qualidade de cidadão de Atenas, a maior e mais famosa cidade, por seu poder e sabedoria, não te envergonhes de só te preocupares com dinheiro e de como ganhar o mais possível, e quanto à honra e à fama, à prudência $\mathrm{e}$ à verdade, e à maneira de aperfeiçoar a alma, disso não cuidas nem cogitas? (PLATÃO, 2001, p. 130).

É interessante notar que, na hora de exercer a sua missão educativa, Sócrates se dirige a um indivíduo, no singular, não a um auditório anônimo, e ele sondará este indivíduo para ajudá-lo a verificar se ele efetivamente é, ou somente pensa ser, sábio; "No caso, porém, de convencer-me de que é carecente de virtude, embora diga o contrário, repreendê-lo-ei por dar pouca importância ao que é de mais valor e ter em alta estima o que de nada vale" (PLATÃO, 2001, p. 130-131). Afinal, as coisas mais importantes têm a ver com a verdade e a virtude, duas realidades que para Sócrates são inextricavelmente unidas, a ponto de a virtude de uma pessoa depender de como ela se relaciona com a verdade.

Ora, o relacionamento com a verdade muda profundamente dependendo do relacionamento com o transcendente, que essencialmente pode se estruturar de três formas diferentes: religiosa, ateia ou mística. O relacionamento de tipo religioso e ateio é um tipo de relacionamento essencialmente dogmático, que pressupõe encontrar nos deuses (mitologia) ou nos homens (sofística) a medida última e inquestionável da verdade de todas as coisas. O que torna ameaçadora a atitude de Sócrates em relação à educação é o seu misticismo filosófico monoteísta, que relativiza tanto o antropomorfismo das verdades consideradas intocáveis pelos religiosos como o antropocentrismo absoluto da visão dos sofistas. "É certo que, pelo seu modo de ser espiritual, Sócrates é incapaz de 'aceitar qualquer dogma'. Mas um homem que vive e morre como ele viveu e morreu tem em Deus as suas raízes" (JAEGER, 1979, p. 540).

Na realidade, a espiritualidade filosófica monoteísta nasce dentro da religiosidade do sagrado mitológico, mas depois se distancia das suas origens mitológicas e se apresenta com características que modificam profundamente a percepção e a relação do homem com a verdade, determinando o conflito a que assistimos no processo a Sócrates, como também no enredo das tragédias deste mesmo período.

Tal como o filho se separa do pai e luta com ele e, no entanto, não poderia ter existido sem ele, assim o pensamento filosófico e a afirmação da pessoa humana contida na tragédia denuncia a insuficiência dos deuses, e entra mesmo em conflito com eles. É o conflito específico que houve na piedade grega e que tem as suas vítimas míticas e reais: Antígona e Sócrates, vítimas, sem dúvida alguma, do sacrifício que os deuses exigem para dar passagem à nova piedade, ao nascimento da consciência. (ZAMBRANO, 1995, p. 54).

A 'nova piedade' socrática se manifesta, de forma incisiva e desafiante, numa frase emble- 
mática da Apologia: "sou mais obediente aos deuses do que a vós" (PLATÃO, 2001, p. 130). Mas esta afirmação, poderíamos perguntar, não é também uma declaração de intransigência e fundamentalismo religioso? Não, porque o 'deus' da espiritualidade filosófica é justamente o apeiron, o não-dogmaticamente definido. Na piedade mitológica antropomórfica deus se identifica com o que é dogmaticamente por nós considerado como verdade, mas Sócrates sempre desmonta ironicamente qualquer manifestação de dogmatismo; "é sua hostilidade não apenas à 'resposta certa', mas quanto à ideia de ser a resposta certa". (JOHNSON, 2012, p. 72, grifo do autor).

Para destacar ainda mais a característica da visão socrática de educação, falta dizer alguma coisa sobre a forma ateia de relacionamento com o transcendente. Johnson (2012, p. 71, grifo do autor) observa que na época de Sócrates “havia - e há desde então, e haverá no futuro - dois tipos fundamentalmente distintos de filósofos. O primeiro lhe diz o que pensar; o segundo como pensar". O primeiro tipo de filósofo, na época de Sócrates, era representado pelos sofistas, que, depois do nascimento da filosofia, são os primeiros pensadores a cortar o laço da verdade com o "divino", se constituindo como um movimento filosófico-cultural que tenta encontrar uma saída do monoteísmo da filosofia pré-socrática. Os sofistas percebem claramente que o que está em jogo no debate filosófico é a própria visão de verdade e que se pode procurar outro significado dela e outro caminho de acesso a ela. Se nós consideramos a verdade como determinada unicamente pela convergência de opiniões e pela autarquia da linguagem, não precisamos mais nos preocupar com uma arcké, que preexistiria antes e independentemente de nós.

Górgias, um dos mais importantes pensadores sofistas, escreve uma obra cujo título expressa de forma clara e provocatória o núcleo desta nova visão: "Sobre a natureza, ou seja, sobre o não-ser". Isso significa: o Ser de Parmênides não existe, como não existe nenhum outro princípio explicativo independente de nós e do poder criativo do nosso logos. É o homem a medida hermenêutica, criadora e ordenadora de todas as coisas, e não uma arcké preexistente e independente de nós, que teria necessariamente características divinas.
Esta "solução" sofistica tem como consequência uma atitude educacional que, excluindo qualquer transcendência da verdade, se exercita mais "no que é chamado de retórica do que em discutir (dialegesthai)" (PLATÃO, 2007, p. 44), como encontramos no diálogo que Platão intitula com o nome do famoso sofista. Nas palavras que Platão coloca na boca de Górgias, a retórica torna-se uma arte com um poder extraordinário. "De fato, o orador é capaz de discursar contra todos e tratar de qualquer questão de modo a conquistar o apoio da multidão, abordando de maneira persuasiva praticamente qualquer assunto que deseje" (PLATÃO, 2007, p. 57).

A retórica sofista, porém, pode funcionar somente admitindo a visão de verdade sofista, coisa que Sócrates não pode admitir. Ele concorda com os sofistas sobre a importância decisiva do uso inteligente do $\log o s$, mas não na forma da retórica e sim na forma do diálogo (diá-logos). Enquanto para os sofistas a retórica visa à criação da verdade, favorecendo eventualmente os mais expertos e inescrupulosos, o diálogo socrático é uma arte parecida à da parteira e visa ajudar as pessoas a descobrir e trazer à luz a verdade escondida nas entranhas da vida.

Nesse sentido, o diálogo socrático é também bem mais democrático que a retórica sofista: no diálogo socrático o saber e o saber falar não se colocam a serviço do que é mais conveniente para os mais sabidos, mas colocam-se a serviço de uma Verdade que transcende os limites do nosso conhecimento e que é igual para todos. Por isso, o diálogo socrático comporta uma espiritualidade que deixa o ser humano sinceramente consciente da própria ignorância e aberto ao Mistério inesgotável de uma Verdade que não é posse exclusiva de nenhum sabido, mas que se deixa vislumbrar por todos aqueles que a procuram dia-logando democraticamente. No Górgias de Platão há uma passagem significativa onde Sócrates convida o sofista Polo a uma atitude pedagógica democrática, com as seguintes palavras: "respeita o sistema de perguntar e ser perguntado alternadamente, [...] podendo assim tanto refutar quanto ser refutado" (PLATÃO, 2007, p. 64).

O distanciamento de Sócrates da paidéia sofista aparece logo na abertura da Apologia, onde se 
desculpa antecipadamente pelo seu jeito de falar, declarando: "não sei absolutamente falar bem"; e considera mentiroso o fato dos acusadores tê-lo apresentado como um hábil orador que poderia enganar qualquer um.

A menos que chamem de orador eloquente quem só diz a verdade. Se é isso o que querem significar, concordarei que também sou orador. Mas, quão diferente deles todos! [...] Não, atenienses, por Zeus, uma oração arrebicada como a deles, com palavras e torneios elegantes, porém de períodos simples e com as expressões que naturalmente me ocorrerem. (PLATÃO, 2001, p. 113).

O relacionamento socrático com a verdade, marcado por uma espiritualidade filosófica monoteísta, caracteriza assim sua atividade educativa mais como uma conversa ocasional e informal entre amigos; uma conversa que se desenrola dentro do rio da vida, com todas as suas desafiantes perguntas que emanam de um fundo de mistério. Sócrates

[...] era parte da vida da cidade - uma parte pensante, com certeza, uma parte que conversa e debate, porém não mais separada de sua atividade pulsante e agitada do que o peixeiro, o cambista ou o sapateiro, o político fanfarrão, o poeta indigente ou o advogado ardiloso. Sentia-se em casa na cidade e um estranho no campus. Sabia que assim que a filosofia se separasse da vida das pessoas, ela começaria a perder a validade e seguiria na direção errada. [...] Pois Sócrates viu e praticou a filosofia não como uma atividade acadêmica, mas como uma atividade humana. Estava relacionada com seres humanos reais enfrentando escolhas reais e éticas entre certo e errado, bem e mal. (JOHNSON, 2012, p. 138).

\section{Considerações conclusivas}

A missão divina do filósofo-educador concre- tiza-se, portanto, em ajudar as pessoas a encarar a busca da verdade e da justiça, percorrendo o estreito caminho entre o dogmatismo e o relativismo absoluto. Isso se torna possível somente por meio de uma atitude de espírito (espiritualidade) que, não satisfeita com as formulações antropomórficas, nem com as invenções antropocêntricas da verdade e da justiça, sabe mergulhar na escuridão luminosa do mistério da vida, experimentando a cada dia a dor e a alegria do pensar.

Nessa altura da nossa análise, podemos então dizer que é a falta "dessa" espiritualidade que se torna prejudicial para a educação, não a falta da piedade tradicional que determinou a acusação contra Sócrates. Essa nova atitude de espírito possibilita uma educação que torna a vida digna de ser vivida, porque nos liberta da arrogância do saber e da angústia da ignorância. Até no momento de encarar nosso último destino, poderemos coerentemente continuar acreditando que também a verdade sobre a morte não nos pertence, repetindo com Sócrates: "Mas, está na hora de nós irmos: eu, para morrer; vós, para viver. A quem tocou a melhor parte, é o que nenhum de nós pode saber, exceto a divindade" (PLATÃO, 2001, p. 147). Reconhecendo, assim, que, até depois de uma vida inteira dedicada à busca da verdade, a nossa maior sabedoria consiste em saber que não se sabe.

Talvez, para nós educadores, isso seja "um modo, mesmo que 'fraco', de vivenciar a verdade, não como objeto de que nos apropriamos e que transmitimos, mas como horizonte e pano de fundo no qual, discretamente, nos movemos" (VATTIMO, 2007, p. XX, grifo do autor). Assim, a verdade "fraca" de um não saber socrático representa a verdadeira força de uma nova atitude gnosiológica e pedagógica, que se coloca como alternativa a qualquer dogmatismo tanto religioso como ateu.

\section{REFERÊNCIAS}

ARISTÓTELES. Metafísica. In: REALE, Giovanni. Ensaio introdutório, texto grego com tradução e comentário. Trad. M. Perine. São Paulo: Loyola, 2001.

BORNHEIM, Gerd (Org.). Os filósofos pré-socráticos. 19. ed. São Paulo: Cultrix, 2011.

DESCARTES, René. Obras escolhidas. Trad. Jacob Guinsburg, Bento Prado Jr., Newton Cunha, Gita Guinsburg. São Paulo: Perspectiva, 2010. (Textos 24). 
HEIDEGGER, Martin. Ensaios e conferências. Trad. E. Carneiro Leão, G. Fogel, M. S. C. Schubach. 2. ed. Petrópolis: Vozes, 2002.

JAEGER, Werner. Paidéia: a formação do homem grego. Trad. A. M. Parreira. São Paulo: Martins Fontes, 1979. JOHNSON, Paul. Sócrates - um homem do nosso tempo. Trad. L. Kommers. Rio de Janeiro: Nova Fronteira, 2012. LEÃO, Emmanuel Carneiro. A história na filosofia grega. In: FERREIRA, Acylene M. C. (Org.). Fenômeno e sentido. Salvador: Quarteto, 2003. p. 17-35.

MONTAIGNE, Michel de. Ensaios. Vol. I. Trad. S. Milliet. São Paulo: Nova Cultural, 1996. (Os Pensadores) PLATÃO. O banquete - apologia de Sócrates. Trad. C. A. Nunes. 2. ed. rev. Belém: Edufpa, 2001. . Górgias. In: Diálogos II. Trad., textos complementares e notas E. Bini. Bauru: Edipro, 2007.

POPPER, Karl. Conjecturas e refutações. Trad. B. Bettencourt. Coimbra: Almedina, 2006.

PRÉ-SOCRÁTICOS. Fragmentos, doxografia e comentários. São Paulo: Nova Cultural, 1996. (Os Pensadores).

VATTIMO, Gianni. O fim da modernidade. Niilismo e hermenêutica na cultura pós-moderna. Trad. E. Brandão. São Paulo: Martins Fontes, 2007.

WEISCHEDEL, Wilhelm. A escada dos fundos da filosofia. Trad. E. D. Gil. São Paulo: Angra, 2000.

ZAMBRANO, María. O homem e o divino. Trad. C. Rodrigues e A. Guerra. Lisboa: Relógio D’Água, 1995.

Recebido em 22.10.2012

Aprovado em 21.01.2013 